\title{
"Virtual" science centre on road to reality
}

Potsdam. The uncertainty hanging over plans to build a science centre at Golm near Potsdam, capital of the east German Land of Brandenburg, was alleviated earlier this month following the local government's approval of funding for construction of the first building.

The move comes only a few weeks after Hans Zacher, president of the Max Planck Society (MPS), claimed that the Brandenburg ministry of science and culture was reneging on its promise to establish the University of Potsdam's faculty of science at Golm. MPS had decided to build three institutes - for colloid and surface research, gravitational physics and molecular plant physiology - at the site on the basis of the ministry's promise.

Before reunification, Brandenburg had

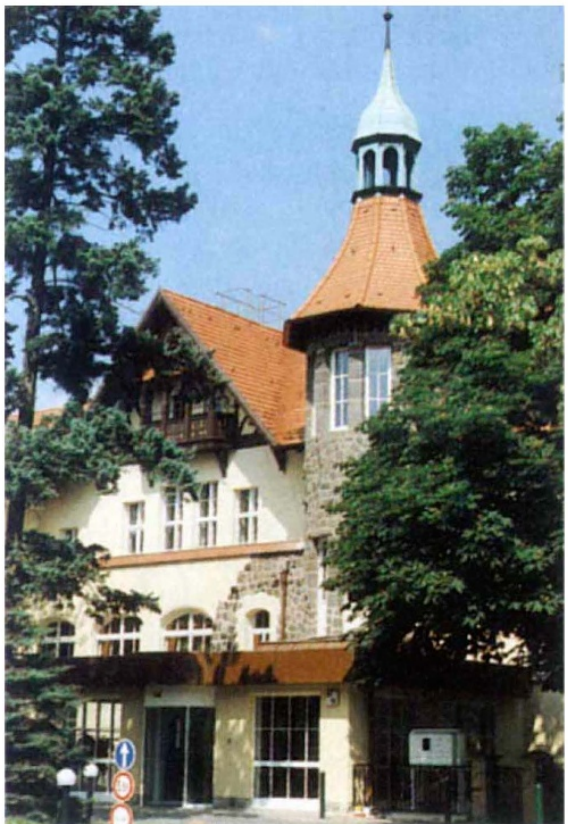

Palatial accommodation: plans to build Potsdam University were approved in 1991.

no universities. Recommendations to build three, along with five Fachhochschulen (technical colleges), were later made by Germany's science council, the Wissenschaftsrat, which assumed responsibility for assessing the science and university landscape in the former East Germany.

Plans to build Potsdam University were subsequently approved in 1991 . The historical New Palace, built for Frederick the Second ("Old Fritz"), king of Prussia during the Napoleonic era, was proposed as the site of the main campus; Babelsberg, an eastern suburb of Potsdam which was the headquarters of the German Red Cross during the Third Reich and later the site of the Jurisprudence Academy, the hub of the East German ideology machine, was chosen for the law faculties and some arts departments.
A site at Golm, which was the headquarters of military espionage during the $1930 \mathrm{~s}$, and later a training school for the Stasi, was chosen as the location of the science centre. The science centre was originally scheduled to begin operating next year, but until now it has seemed unlikely that building work would even begin by that date.

Speaking at a meeting in June, Zacher warned Brandenburg that failure to honour its commitments could cause MPS to move its institutes elsewhere.

"New unforeseen difficulties for the state," he said, "also put our plans in question."

The university believes that Zacher's strong words shamed the Brandenburg

government into action, after months of vacillation. But Heinz-Ulrich Schmidt, head of science at the ministry of science and culture, argues that the decision, which he says came after a long but routine bureaucratic process, was in any case expected this month. "Golm is a very high priority for us," he adds.

Schmidt says that the first building of the science faculty could be operating by 1997. The university, which complains that the science faculty is at present in unsuitable and overcrowded offices in the New Palace, says that a date near the end of the decade is more realistic.

The MPS now says that either starting date would be acceptable.

Alison Abbott

\section{South Africa's ivory towers turn towards townships}

Cape Town. The goals of publicly funded research in South Africa's universities, technikons and museums will be reorganized over the coming months to meet the needs of the Reconstruction and Development Programme (RDP), a scheme which enjoys cross-party support in the government of national unity and which is intended to improve basic living conditions and promote economic growth.

The Foundation for Research Development (FRD) now spends R70 million (US\$19 million) annually, with around 60 per cent available to any area of research.

But FRD will end its existing funding schemes at the end of the year. Meanwhile, researchers have been asked to submit proposals within four new strategic themes: "Competitive industry", "Improved quality of life", "Sustainable environment" and "Effective science, engineering and technology education and awareness".

To take part in the new programmes, researchers must submit by the end of next month their proposals for grants of up to five years, although many have complained that the deadline is too short.

More general proposals will also qualify, provided they are aimed at "building and enhancing research capacity", while money will also be available for studentships, fellowships and equipment and for developing a research culture in historically disadvantaged institutions.

FRD says that all proposals must be internationally competitive, involve collaboration with industry and include measures that favour blacks and women. Specific budgets will be attached to each programme only after the volume, quality and costs of the submissions has been assessed, according to Gerhard von Gruenewaldt, vice-president of the FRD.

FRD's plans have been applauded by many scientists as a careful response to the challenge to the country's scientists to "come up with suggestions on how they can contribute to the development of South Africa", made earlier this year by Bernie Fanaroff, deputy director-general of RDP (see Nature 374, 664; 1995).

But Roy Siegfried, director of the Fitzpatrick Institute of Ornithology at the University of Cape Town, expresses the concerns of others when he describes FRD's plans as an "over-elaborate attempt to partition research into themes which have areas of considerable overlap".

Siegfried argues that FRD should have delayed its reorganization until the release of a government white paper on science and technology policy that Ben Ngubane, the minister for arts, culture, science and technology, has promised will follow the soon-to-be-finished audit of the activities of the research councils.

The specific programmes and their contents were chosen on the basis of a broad consultation with the scientific community, says von Gruenewaldt.

But the increased emphasis on applied research in FRD's plans has also caused concern that this may be funded at the expense of basic research unless extra money is forthcoming from the government. Michael Cherry 